\title{
CONTRIBUIÇÃO AO CONHECIMENTO DAS ROCHAS GRÁNITÓIDES DO SUL DO BRASIL
}

\author{
EBERHARD WERNICK* e FAUSTINO PENALVA**
}

\begin{abstract}
In this paper, the authors make an attempt to present a synthesis on the problem of granitic rocks of Southern Brazil related to the Ribeira Folded Belt, tectonically compartmented in "folded systems" and "massifs"; these rocks belong to the "Brasiliano Cycle" (corresponding to Baykalian Cycle, Upper Precambrian).

Granites are of cata-, meso- or epitectonic type, forming simple or polydiapiric intrusions. The big polydiapiric intrusions (cata- or mesotectonic) are controlled by faults, which separate massifs from folded systems; mesotectonic simple intrusions are controlled by folding structures or faults, and the epitectonic (related to the molassic phase) are fracturecontrolled. Also the alkali granites are intrusions controlled by faulting.

Frequency of granitic bodies is variable in the different massifs and folded systems; composition varies from diorites to true granites, calco- alkalic to alkalines. Mineral deposits, always of small importance, are of varied distribution, including occurrences of Sn, $\mathrm{W}, \mathrm{Cu}, \mathrm{Pb}$, and $\mathrm{Au}$.

Late tectonic bodies are the most common; the syntectonic are restricted to the massifs and the post-tectonic ones are rare and of small size.

Some late- to post-tectonic bodies are migmatite-forming granites. The sequence syn-, late- and post-tectonic granites is continuous, without sharp breaks or time intervals.

The granitic magmatism of the Ribeira Foldrd Belt is very typical of geosynclinal areas with weak or absent basic volcanism during subsidence phase, with weak acid magmatism at the differentiation phase and strong granitic magmatism (intrusive and extrusive) during the "closure" phase (a typical behavior of geosynclinal areas with sialic profile).
\end{abstract}

INTRODUÇÃo No decorrer dos últimos anos, o panorama geológico brasileiro se caracterizou por um crescente e contínuo açúmulo de informações acerca da geologia do sul do país, através de mapeamentos sistemáticos regionais e de estudos de detalhe, ligados a problemas geológicos, estruturais, petrołógicos, geocronológicos, econômicos e estratigráficos de suas áreas cristalinas Pré-Cambrianas. Esta soma de informações, ainda que insuficiente sob muitos aspectos, já permite a elaboração dos primeiros trabalhos de síntese de caráter preliminar, envolvendo a área em questão.

No presente trabalho, os autores apresentam uma visão geral das rochas graníticas do sul do Brasil, abordando aspectos de campo, petrográficos; estruturais, econômicos e evolutivos, no sentido de tentar a sua caracterização global ao nível dos conhecimentos ora disponíveis.

* Departamento de Mineralogia c Recursos Minerais, Instituto de Geociências e Ciências Exatas, ,UNESP - Rio Claro, SP.

** Instituto de Geociências, Universidade de São Paulo (USP). 
I - PANORAMA GEOLÓGICO DO CRISTALINO SUL-BRASILEIRO A região em foco é formada por uma sucessão de faixas com disposição geral NE-SW, alternadamente constituída de rochas epimetamórficas (Faixas de Dobramento) e rochas meso- e catazonais (Maciços Medianos), integrantes do Sistema de Dobramentos Ribeira (Hasui et al. 1975). De NW para SE, os epimetamorfitos correspondem às Faixas de Dobramentos Apiaí, Tijucas e Uruguai Oriental, e as rochas mesoe catazonais aos Maciços Medianos de Joinvile e Pelotas (Fig. 1).

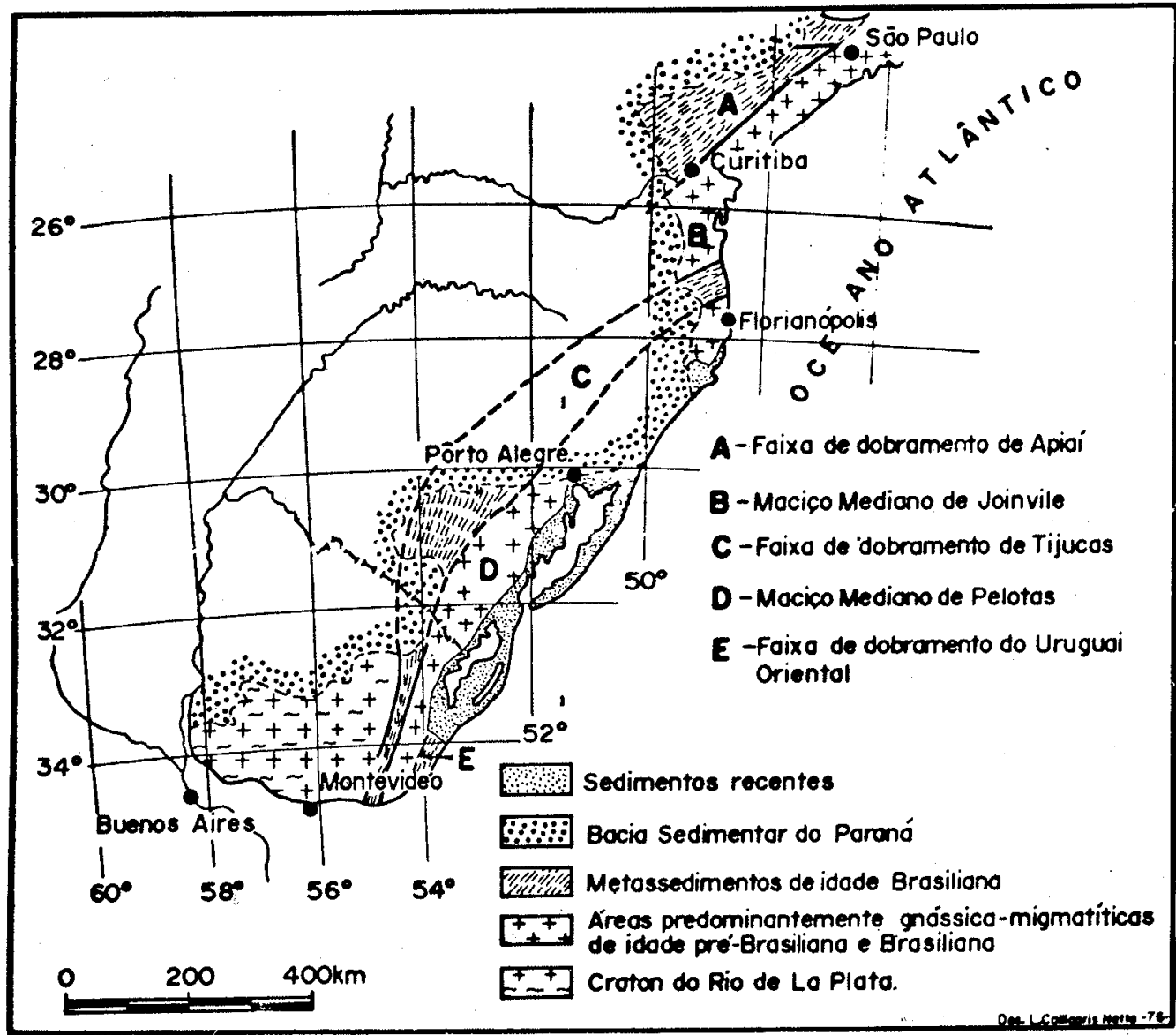

Figura 1 - Estruturação do Sistema de Dobramento Ribeira, segundo Hasui et al. (1975)

A Faixa de Dobramento Apiaí engloba os Grupos São Roque (SP) e Açungui (PR); a Faixa de Dobramento Tijucas é formada pelos Grupos Brusque (Formação Botuverá, SC), Porongos (Formação Vacacaí, RS) e Lavalleja (Uruguai); a Faixa de Dobramento do Uruguai Oriental, de pequena expressão, é constituída pelo Grupo Rócha. 
As Faixas de Dobramentos são constituídas por rochas ectiníticas, representadas por metassedimentos clássicos grossos e finos (conglomerados, arenitos, ritmitos, siltitos. argilitos), clasto-químicos (arenitos calcíferos e margas) e químicos (calcários, calcários dolomíticos e dolomitos). Falta a seqüência ofiolítica típica da fase de subsistência, assim como é raro material vulcânico da fase de diferenciação geossinclinal. Toda a seqüência ectinítica, predominantemente epizonal, é cortada por abundantes corpos graníticos. Minerais índices caracterizam a região como tendo sofrido metamorfismo de baixa e média pressão (Hasui et al., 1975).

Os Maciços Medianos são de história geológica bastante complexa. São constituídos por granulitos, charnockitos, rochas ultrabásicas, gnaisses, migmatitos, anatexitos, granitóides, xistos, anfibolitos. Quartzitos, itabiritos e rochas carbonáticas são raros. São unidades polimetamórficas com idades variáveis entre 3.000 e $500 \mathrm{~m} . \mathrm{a} .$, com rochas referíveis aos Ciclos Guriense ( $>3.000 \mathrm{~m} . \mathrm{a}$.); Jequié ( $\sim$ 2.800 m.a.), Transamazônico ( 2.000 m.a.) e Brasiliano ( 1.000-500 m.a.) (Almeida, 1971). Correspondem a faixas crustais muito antigas, sucessivamente remobilizadas e, em parte, representam porções profundas das faixas de dobramentos epimetamórficos brasilianos. À semelhança destas, também os Maciços Medianos são cortados por abundantes corpos granitóides (Hasui e Sadowski, 1976).

O Maciço Mediano de Joinvile é constituído pelos Complexos Critalinos dos Estados de SP e PR, pela Formação Setuva (PR), assim como pela parte norte do Complexo Taboleiro (SC) e pela extremidade oriental do Escudo Sulriograndense (RS). O Maciço Mediano de Pelotas engloba a parte sul do Grupo Taboleiro (SC), a Formação Cambaí (RS), bem como parte do Complexo Cristalino do Uruguai.

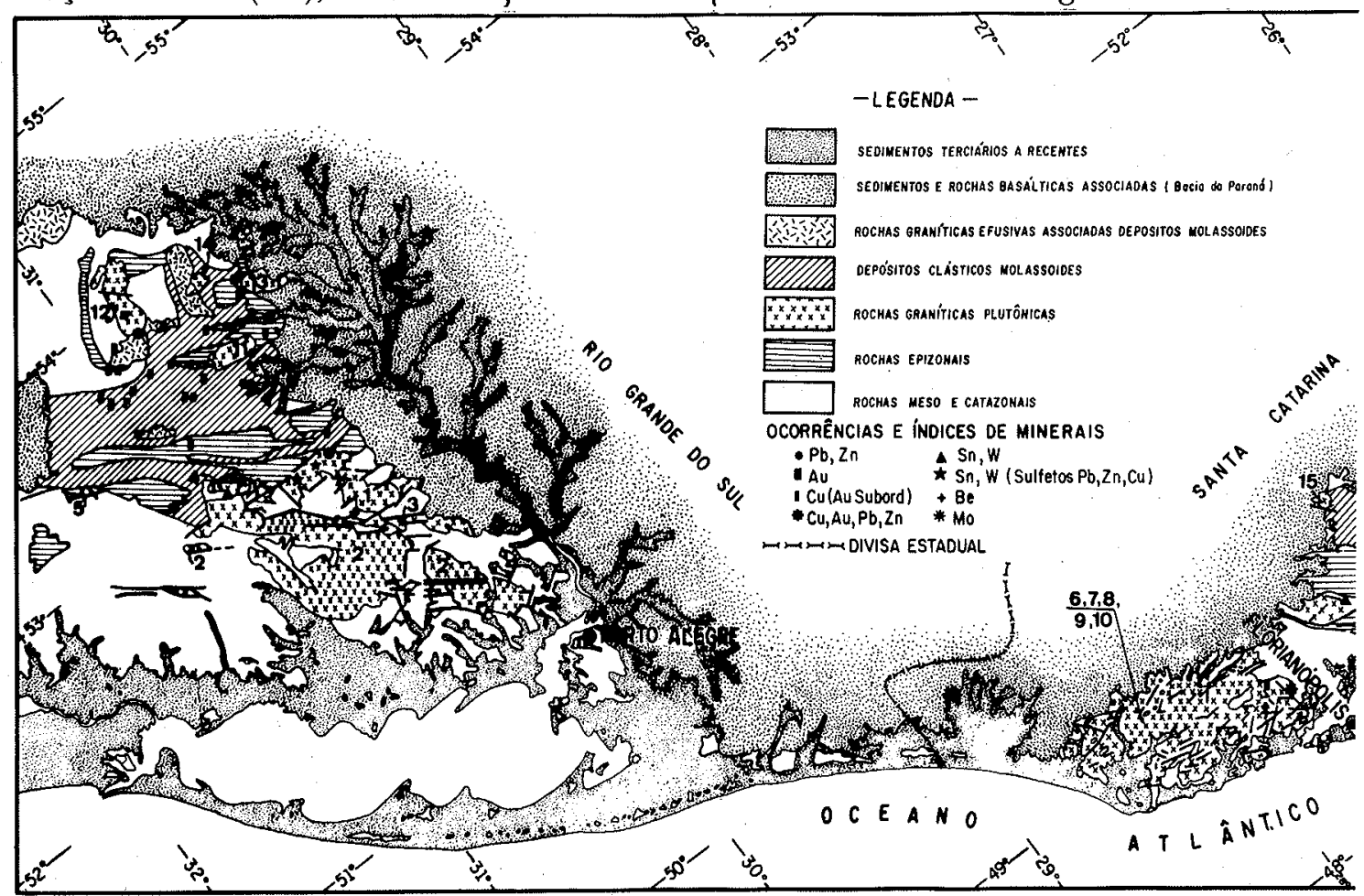

Figura 2 - Principais corpos graníticos do Sistema de Dobramento Ribeira 
O Sistema de Dobramento Ribeira, acha-se limitado a leste pelo Oceano Atlântico, a sudeste pelo Cráton La Plata e a oeste pela cobertura sedimentar-vulcânica da Sinéclise do Paraná. O seu limite nordeste ainda não foi claramente definido, correspondendo à Zona Cristalina Norte de São Paulo, constituída pelos Grupos Amparo, Paraíba, Pinhal e Itapira, também rica em granitóides brasilianos (vide Fig. 2).

Junto aos contatos entre as faixas de dobramento e os maciços de natureza eminentemente tectônica [Hennies et al.(1967), Hasui et al.(1969), Picada (1971)], bem como no interior destes, ocorrem depósitos molassóides associados a efusivas e piroclasitos, ácidos a intermediários, depositados em bacias tectônicas [Trein e Fuck (1967), Mau (1962), Almeida (1969), Ebert (1971)]. Constituem a Formação Maricá e os Grupos Bom Jardim e Camaquã (RS), o Grupo Itajaí e a Formação Garcias (SC), o Grupo Castro e as Formações Campo Alegre, Guaratubinha e Camarinha (PR), além do Grupo Eleutério (SP) e da Formação Pouso Alegre (MG).

Dados geocronológicos $(\mathrm{Rb} / \mathrm{Sr}, \mathrm{K} / \mathrm{A})$ indicam que as rochas das faixas de dobramentos foram geradas no Ciclo Brasiliano (Baikaliano) com a seguinte evolução geológica (Cordani e Bittencourt, 1967):

1. Entre 650 e 600 m.a.: metamorfismo principal e formação de granitos sintectônicos;

2. Entre 590 e 500 m.a.: intrusão dos granitos tardi- e pós-tectônicos; formação de depósitos molássicos;

3. Cerca de 450 m.a.: alçamento regional de cadeias montanhosas; formação de depósitos molássicos.

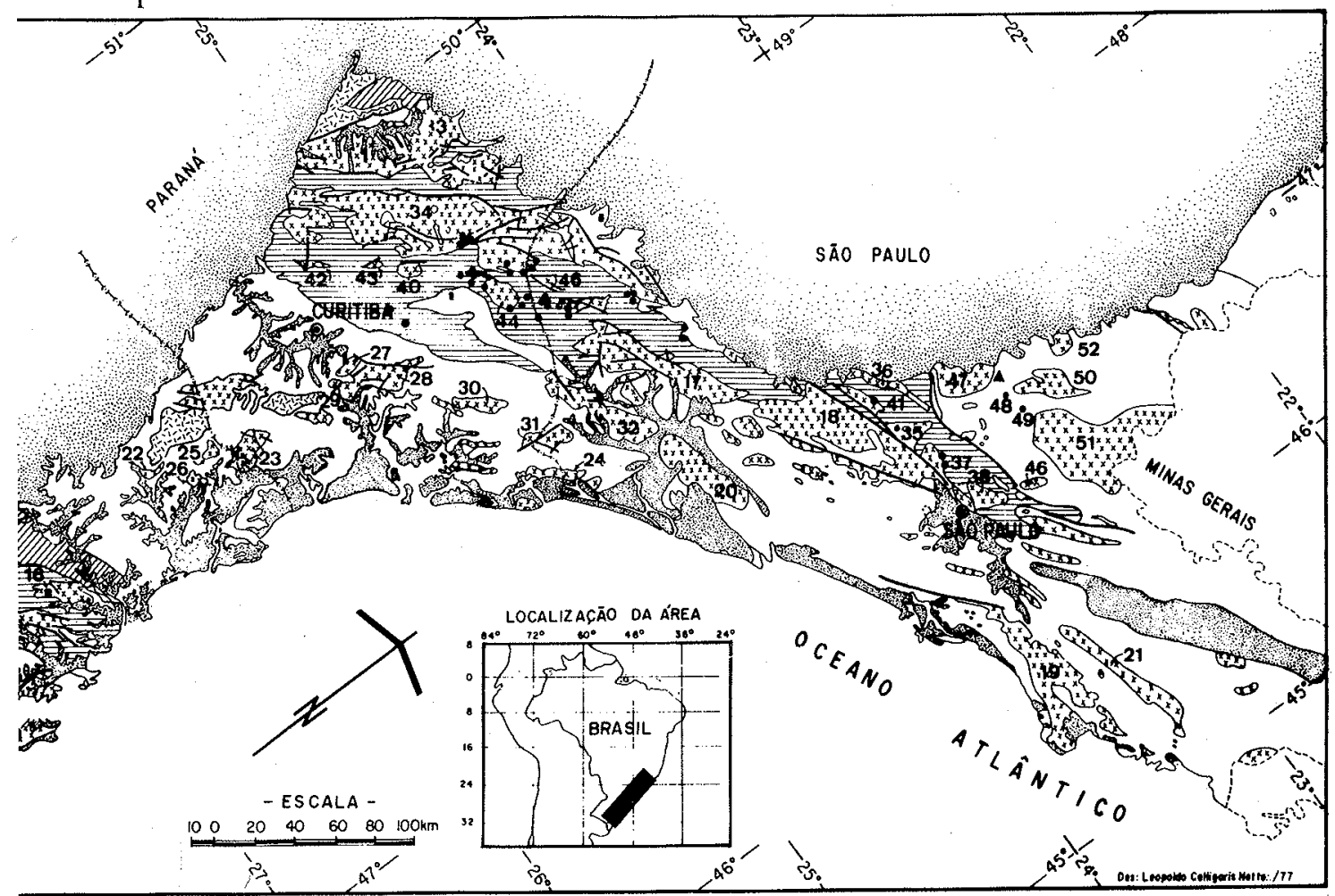

Figura $2-($ continuaçẫo $)$ 


\section{A: MACIÇO MEDIANO DE PELOTAS}
1. Encruzilhada
4. Campina
2. Dom Feliciano
5. Prestes
3. Cordilheira
6. Morro da Fumaça
7. Jaguaruna
8. Rio Chicão
9. Imaruí
10. Palmeira do Meio

\section{B: FAIXA DE DOBRAMENTO TIJUCA}

11. Caçapava

12. Jaguari-Lavras

\section{São Sepé \\ 14. Ramada}

C: MACIÇO MEDIANO DE JOINVILE

17. Agudos Grandes

18. Piedade

19. Cachoeira

20. Itariri

21. Paraibuna
22. Corupá
23. Morro Redondo
24. Mandira
25. Dona Francisca
26. Piraí

15. Valsungana

16. Guabiruba

\section{D: FAIXA DE DOBRAMENTO APIAÍ}

33. Cunhaporanga

34. Três Córregos

35. São Roque

36. Sorocaba
37. Itaqui
38. Cantareira
39. Serra Grande
40. Morro Grande
41. São Francisco

27. Anhangava
28. Graciosa
29. Marumbi
30. Barra do Turvo
31. Guaraú
32. Itapeuna

\section{E: ZONA CRISTALINA NORTE}
47. Itú
49. Nazaré
51. Socorro
52. Jaguariuna
48. Atibaia
50. Morungaba

42. Cerne

43. Piedade

44. Itaóca

45. Espírito Santo

46. Apiaí

No presente trabalho só serão abordadas as porçōes do Sistema de Dobramento Ribeira expostas no Brasil, omitindo-se a sua área de ocorrência no Uruguai.

II - ROCHAS GRANITÓIDES DO MACIÇO DE PELOTAS Os granitos do Maciço Mediano de Pelotas ocorrem aglutinados em dois grandes complexos situados na zona tectônica entre o Maciço Mediano de Pelotas e a Faixa de Dobramento Tijucas. São os Complexos Gáúcho e Pedras Grandes, respectivamente situados ao sul de Porto Alegre e Florianópolis e com áreas de cerca de 10.000 e $8.400 \mathrm{~km}^{2}$. O primeiro é formado pelos granitos Dom Feliciano, Encruzilhada, Prestes, Cordilheira, Arroio dos Ladrões, Figueiras, Cerro Frio e Campinas; o segundo pelos granitos Imaruí, Morro da Fumaça, Rio Chicão, Jaguaruna e Palmeira do Meio (Leinz, 1945; Tessari e Picada, 1966; Tessari e Figueiredo Filho, 1966; Ribeiro et al, 1966; Picada, 1967; Castro e Castro, 1969; Teixeira, 1969; Ferreira, 1969; Schulz et al, $1970)$. 
Os complexos são de natureza polidiapírica (Stephansson, 1975) com corpo sin-, tardi- e pós-tectônicos*, nos quais os mais jovens cortam ou rodeiam as intrusi vas mais antigas (Fig. 3A). São intensos os fenômenos de remobilização e metasso matismo. A composição dos diversos granitos varia de quartzo diorítica a granítica incluindo termos monzoníticos, adamelíticos e granodioríticos. A sua natureza varí de calco-alcalina a subalcalina, atingindo localmente caráter alcalino. Ocorrer corpos equigranulares e porfiróides, leuco- e mesocráticos. Entre as intrusões e no: corpo mais antigos ocorrem intercalações de rochas encaixantes.

Os contatos entre as diversas intrusões são tanto nítidos quanto difusos e fre qüentemente tectônicos. Os contatos entre os complexos e as encaixantes do Maciçc Mediano de Pelotas são difusos ou gradacionais, com freqüente interdigitação entre gnaisses e granitos que leva à formação de migmatitos (Härme, 1965). Outras vezes são intrusivos, concordantes a discordantes, ou tectônicos. Em relação às rochas encaixantes da Faixa de Dobramento Tijucas são nitidamente intrusivos, discordantes, ou tectônicos. Em todo o Maciço Mediano de Pelotas ocorrem, com maior ou menor freqüência, diques e "plugs" de granitos pórfiros ligados à fase de descompressão generalizada, que caracterizou o fim da fase tectônica brasiliana.

Dados geocronológicós $\mathrm{Rb} / \mathrm{Sr}$ e $\mathrm{K} / \mathrm{A}$ (Teixeira, 1969; Cordani et al, 1974), revelaram para a fase sintectônica idade de $650 \mathrm{~m}$.a., para a fase tarditectônica 610 m.a. e para os granitos pós-tectônicos, 550 m.a.

Os principais recursos metálicos do Maciço Mediano de Pelotas são representados por mineralizaçōes de metais raros $\mathrm{W}, \mathrm{Sn}, \mathrm{Be}, \mid \mathrm{Mo}, \mathrm{Nb}, \mathrm{Ta}, \mathrm{Li}$ e F, que constituem depósitos ou ocorrências intra- e, predominantemente, peribatolíticas. As segundas localizam-se tanto em ectinitos quanto em migmatitos da faixa de contato entre o Maciço Mediano de Pelotas e a Faixa de Dobramento Tijucas, representada pela Dorsal do Canguçu.

III - ROCHAS GRANITÓIDES DA FAIXA DE DOBRAMENTO TIJUCAS Os granitos nesta faixa são relativamente raros. Podem ser agrupados em dois tipos: 1) os intrusivos nas epimetamórficas e 2) os associados aos depósitos molassóides. Os primeiros são representados pelos granitos Caçapava do Sul, JaguariLavras, Valsungana e Guabiruba e os segundos pelos granitos São Sepé, Ramada e Subida (Carvalho e Pinto, 1938; Leinz et al, 1941; Maack, 1974; Melcher e Mau, 1960; Goñi, 1961 Schulz et al, 1969; Jost, 1970; Knijnik e Pozza, 1971).

Os primeiros são corpos mesotectônicos de dimensões médias e circunscritos, e ocorrem sob a forma de domos. São tantos discordantes quanto concordantes e exibem porções marginais com foliação cataclástica e núcleos centrais geralmente maciços. Ostentam auréolas de contato e irradiação de pegmatitos e aplitos. São corpos de polidiapirismo restrito, com facies tardi- e pós-tectônicas. Seu alojamento é controlado pelas estruturas dobradas, ocorrendo em núcleos de anticlinais. Greisenização, metassomatose e remobilização são raras. São rochas de composição variável entre diorítica e granítica, predominando amplamente esta; comumente são porta-

* A classificação dos corpos granitóides, quanto ao seu caráter tectônico, em pré-, sin-, tardi- e póstectónicos (Marmo, 1971) e em epi-, meso- e catatectônicos (Stephansson, 1975), desde que não feita pelos autores citados no presente trabalho, foi inferida com base nas descriçōes geológicas e petrográficas disponíveis. 
doras de ortoclásio. A textura é predominantemente equigranular, associada a termos porfiróides e com textura "rapakivi". As mineralizações diretas ou indiretas vịnculadas a estes granitos, com facies tardi- e pós-tectônicas, são de $\mathrm{Cu}, \mathrm{Sn}, \mathrm{Au}$, além de indícios de $\mathrm{Pb}$ e $\mathrm{Zn}$.

Os granitos do segundo grupo são corpos epitectônicos, pequenos, geneticamente ligados às efusivas da fase molássica. Constituem intrusões pós-orogênicas nos depósitos molassóides, ou nas epimetamórficas da Faixa de Dobramento Tijucas. Exibem contatos discordantes e "chilled margins"; foliação cataclástica falta nas zonas marginais. Associados a esses corpos, ocorrem diques de basaltos, andesitos, lamprófiros e granófiros. As intrusões são controladas por fraturamento e em alguns casos exibem zoneamento litológico.

São de composição variável entre granodiorítica e granítica, predominando amplamente esta. Sua textura é geralmente equigranular e ortoclásio é o feldspato alcalino mais freqüente.

Datações geocronológicas referentes aos granitos da Faixa de Dobramento Tijucas (Minioli e Kawashita, 1971; Cordani et al., 1974), revelaram para os granitos Caçapava e Jaguari-Lavras história evolutiva complexa, com uma fase de 610 m.a. e outra de 525 m.a. Os granitos de filiação molássica (Ramada, Subida e São Sepé), exibem idade de $525 \mathrm{~m}$.a.

Ao lado das rochas graníticas, adquirem expressão na Faixa de Dobramento Tijucas as rochas vulcânicas da fase molassóide. São representadas por riolitos, dacitos, andesitos e subordinadamente basaltos, referíveis às Formações Hilário, Acampamento Velho e Rodeio Velho.

Considerando-se os dados geocronológicos disponíveis para a Faixa de Dobramento Tijucas e a área limítrofe com o Maciço Mediano de Pelotas,. podem ser caracterizadas para esta região as seguintes fases tectônico-magmáticas:

650 m.a. - Intrusão de granitos sintectônicos ao longo da Dorsal do Canguçu.

610 m.a. - Intrusão dos granitos tarditectônicos de Lavras e Caçapava, e efusão dos andesitos da Formação Hilário.

550 m.a. - Intrusão dos granitos pós-tectônicos ao longo da Dorsal do Canguçu. 525 m.a. - Intrusão das fases pós-tectônicas dos granitos Lavras e Caçapava, penetração dos granitos Ramadas e São Sepé e extrusão das efusivas da Formação Acampamento Velho e Rodeio Velho.

Os mecanismos de intrusão e efusão são controlados por falhas, a maioria das quais de natureza profunda.

Os principais depósitos metáliços da Faixa de Dobramento Tijucas, representados por $\mathrm{Cu}$ e $\mathrm{Au}$, demonstram uma conexão espacial e temporal com as atividades tecto-magmáticas plutônicas e vulcânicas. Estes depósitos metálicos concentram-se nas rochas efusivas, piroclásticas, clásticas e pelíticas dos depósitos molassóides e subordinadamente nos ectinitoș e rochas graníticas.

IV - ROCHAS GRANITÓIDES DO MACIÇO MEDIANO DE JOINVILE Os granitos do Maciço Mediano de Joinvile (Maack, 1961; Fuck et al., 1967; Coutinho. 1972; Hasui, 1973; Melcher et al., 1973; Sadowski, 1974; Hasui e Sadowski, 1976), ocorrem grosseiramente agrupados segundo 3 faixas distintas com orientação geral NE-SW. As duas primeiras (faixas NW e central) são formadas por grandes batólitos predominantemente polidiapíricos envolvendo fases sin-, tardi- e pós-tectônicas. A 
terceira (SE) engloba principalmente intrusões pós-tectônicas menores de caráter alasquitíco ou alcalino.

A primeira faixa se situa ao longo do contato, essencialmente tectônico, entre o Maciço Mediano de Joinvile e a Faixa de Dobramento Apiaí, de tal modo que os complexos graníticos exibem contatos tanto com rochas epizonais a NW quanto com rochas meso- a catazonais a SE. Os principais representantes desta faixa são os complexos de Agudos Grandes e Piedade formando, possivelmente, um só grande complexo com cerca de 200 por $20 \mathrm{~km}$ e com disposição geral paralela às estruturas regionais. São de caráter polidiapírico, com rochas sin- e tarditectônicas cortadas ou rodeadas por corpos pós-tectônicos. Ostentam composição variável entre quartzo-diorítica a granítica, predominando os termos adamelíticos. São constituídos tanto de rochas equigranulares quanto, predominantemente, porfiróides.

Parte dos granitos porfiróides adamelíticos, principalmente os mais foliados, são muito heterogêneos e exibem patentes sinais de fenômenos metassomáticos, representados por intensa blastese de megacristais de microclina. São comuns intercalações mais ou menos extensas de rochas encaixantes mesozonais com disposição paralela à lineação dos corpos. Seus contatos com as rochas graníticas são ora nítidos ora difusos. Os contatos entre os complexos e as rochas encaixantes do Maciço Mediano de Joinvile são variáveis, desde gradacionais, difusos, até nítidos, quer intrusivos quer tectônicos. Já os contatos com as rochas epizonais da Faixa de Dobramento Apiaí são tanto tectônicos quanto nitidamente intrusivos.

A faixa central é bastante semelhante à faixa NW, englobando complexos tanto predominantemente sintectônicos, com feições anatexíticas, quanto complexos polidiapíricos com corpos sin-, tardi- e pós-tectônicos (Complexos Cachoeira, Itariri e Paraibuna, entre outros). Esta fạixa é formada por um número maior de corpos mas de menores dimensōes em relação à faixa NW.

A faixa SE é formada por corpos reduzidos (60-200 $\left.\mathrm{km}^{2}\right)$, alasquíticos ou de tendência alcalina, alinhados grosseiramente segundo duas linhas. São corpos póstectônicos cujos contatos são intrusivos nítịdos, ou tectônicos e de caráter concordante a discordante. Junto aos contatos ocorre localmente brechação e irradiação de diques e veios. A linha norte é formada pelos corpos Corupá, Morro Redondo, Mandira, Dona Francisca e Piraí e ó alinhamento sul pelos corpos Anhangava, Graciosa, Marumbi, Barra do Turvo e Guaraú. Relacionados a estas duas linhas, ocorrem os depósitos molássicos clásticos e efusivos do Grupo Castro e da Formação Campo Alegre, depositados em bacias tectônicas. Condicionamento tectônico de intrusões pós-tectônicas, através de fraturas, é também observado em relação aos granitos associados ao falhamento de Cubatão, a sul da cidade de São Paulo.

Ligados à fase de descompressão regional, no final do Ciclo Brasiliano, ocorrem numerosos diques e "plugs" de granitos pórfiros.

Dados geocronológicos referentes aos granitos e vulcânicas do Maciço Mediano de Joinvile (Vandoros e Franco, 1966; Cordani e Bittencourt, 1967; Ebert, 1971; Cordani e Kawashita; 1971; Minioli, 1971; Cordani, 1974) indicam para a fase sintectônica $650 \mathrm{~m}$.a. A fase tarditectônica é da ordem de $600 \mathrm{~m}$.a. e os granitos póstectônicos têm cerca de $540 \mathrm{~m}$.a. A fase vulcânica molassóides situa-se ao redor de 425 m.a. Este último dado foi questionado (Ebert, 1971).

O Maciço Mediano de Joinvile caracteriza-se, de modo geral, pela ausência pelo menos até a presente data, de ocorrências metálicas de valor econômico, quer nos granitos quer nos dépósitos molássicos. A ausência de maiores mineralizações de $\mathrm{W}$ e 
Sn junto aos contatos entre o Maciço Mediano de Pelotas, a Faixa de Dobramento Tijucas e a Faixa de Dobramento Apiaí, sugere que as falhas que limitam o Maciço Mediano de Pelotas foram menos profundas e intensas que as da Dorsal do Canguçu, implicando em atividade magmática granítica menos intensa. Outro fato que chama a atenção é a falta de registro, até o momento, de concentrações metálicas notáveis ligadas aos granitos alcalinos, o que contrasta com os dados disponíveis para este tipo de rocha na literatura mundial, principalmente para cinturões modernos. Neste sentido os autores sugerem maiores inviestigaçōes nestes corpos.

V - ROCHAS GRANITÓIDES DA FAIXA DE DOBRAMENTO APIAĨ As rochas graníticas perfazem cerca de $50 \%$ da área de exposiçāo da Faixa de Dobramento Apiaí (Moraes Rego e Souza Santos, 1938; Coutinho, 1953 e 1972; Franco, 1958; Ellert, 1964; Fuck et al., 1967; Hasui et al., 1969; Melcher et al., 1973; Hasui, 1973; Wernick e Gomes, 1974). Constituem complexos batolíticos com várias centenas de quilômetros quadrados (granitos Cunhaporanga, Três Córregos, São Roque, Sorocaba, Itaqui, Cantareira, Serra Branca), corpos com dimensões intermediárias (granito Morro Grande, Itaoca, São Francisco, São Miguel Arcanjo, Mairiporã) e bossas e "stocks" com dimensões reduzidas (Granito Cerne, Piedade, Varginha, Espírito Santo, Apiaí, Capuava, Barreiro, Perús, Tico-Tico, Pirapora). São do tipo tardi- e pós-tectônicos, circunscritos, alóctones. As massas graníticas com dimensões pequenas a médias ou são expansões laterais de corpos maiores, ou intrusões independentes. Os corpos maiores ostentam usualmente forma alongada, paralela às estruturas regionais.

Os complexos desta faixa são do tipo mesotectônico e de polidiapirismo restrito (Fig. 3B). A primeira feição é revelada pelo controle de sua intrusão através das estruturas dobradas, (alojamento em núcleos de anticlinais e anticlinórios), concordância estrutural (aliada a numerosas discordancias locais), auréolas e brechas de contato, irradiação de corpos filonares através das encaixantes, amarrotamento local destas e a presença de xenólitos mais ou menos assimilados. Em vários corpos ocorre alinhamento marginal dos minerias, feições protocataclásticas e ativo tectonismo de borda, sugerindo penetração forçada. O caráter polidiapírico restrito é evidenciado pela heterogeneidade dos complexos maiores (cuja composição varia de quartzo-diorítica a granítica), pela associação entre granitos tardi- e pós-tectônicos, com os segundos cortando os primeiros (e.g., granito Carambeí intrusivo no Granito Cunhaporanga) ou rodeando-os (caso dos Granitos Cerne, Varginha, Piedade e Ribeirão Branco, associados ao Granito Três Córregos).

Entre os granitos tarditectônicos, que é o tipo mais freqüente, predominam rochas porfiróides de composição adamelítica, constituídos por matriz cinza, quartzodiorítica a granodiorítica, na qual estão inseridas quantidades variáveis de megacristais cinza claros ou rosados de microclina com 2 a $5 \mathrm{~cm}$. Os granitóides póstectônicos são equigranulares, homogêneos, cinzentos ou rosados e de composição granítica. Geralmente são de reduzidas dimensōes. Alguns corpos são caracterizados por texturas pegmatóides e ricos em minerais acessórios de origem pneumatolítica.

Somam-se às rochas plutônicas, as ocorrências de rochas efusivas do Grupo Castro representantes da fase vulcânica molássica. Ocorrem em bacias tectônicas e incluem riolitos, dacitos, andesitos e material piroclástico. Toda a faixa contém, também, diques e "plugs" de granitos pórfiros ligados à generalizada descompressão da fase pós-tectônica. 
As principais mineralizações metálicas da Faixa de Dobramento Apiaí são re, presentadas por mais de uma centena de ocorrências de $\mathrm{Pb}, \mathrm{Zn}, \mathrm{Cu}, \mathrm{Ag}, \mathrm{Au}, \mathrm{F}$ e Ba, e alguns depósitos de importância econômica, situados quase sempre em calcários. As ocorrências da região do Vale do Ribeira localizam-se dentro de uma faixa lenti cular com extensão de $80 \mathrm{~km}$ e largura máxima de $20 \mathrm{~km}$, situada a SE do granito Três Córregos. Não são conhecidas ocorrências afastadas mais de uma dezena de quilômetros de corpos graníticos.

Dados geocronológicos indicam para os granitos tarditectônicos idades ao redor de $620 \mathrm{~m}$.a. e para os granitos pós-tectônicos cerca de $540 \mathrm{~m}$.a. As efusivas molássicas do Grupo Castro são datadas em torno de 425 m.a. (Cordani e Bittencourt, 1967; Fuck e Trein, 1967; Gordani e Kawashita, 1971; Hasui e Hama, 1972; Cordani, 1974).

VI - ROCHAS GRANITÓIDES DA ZONA CRISTALINA NORTE DE SÃO PAULO As rochas graníticas da Zona Cristalina Norte de São Paulo ocorrem distribuídas em 3 áreas com características distintas. A área SE situa-se junto ao contato tectônico entre a Zona Gristalina Norte de São Paulo e a Faixa de Dobramento Apiaí. É constituída por uma série de corpos isolados, circunscritos, mesotectônicos, simples e de caráter tardi- ou pós-tectônicos (granito Itu, Ponunduva, Jundiaî, Atibaia, Nazaré Paulista, etc.), de dimensões médias e pequenas. São de composição variada, entre granodionítica e granítica, predominando esta. Sua textura é equigranular ou porfiróide. Exibem contatos discordantes, irradiaçã̃o de veios e apófises, tectônica de borda mais ou menos intensa, xenólitos. O metamorfismo de contato é pouco nítido dado o caráter gnáissico-anatexítico das rochas encaixantes.

A área central é formada por complexos cata- e mesotectônicos, polidiapíricos, com fases sin-, tardi- e pós-tectônicas (e.g., Complexos Morungaba, Piracaia e Socorro). São de composição dionítica e granítica, compostos por rochas anatexíticas, porfiróides e equigranulares. Os corpos pós-tectônicos tanto cortam os mais antigos (Complexos de Morungaba e Socorro) quanto os rodeiam (granitos Itatiba e Jaguariuna, que circundam o Complexo Morungaba). As relações entre as diferentes fases intrusivas são complexas, os contatos gradacionais, difusos ou intrusivos nítidos (concordantes a discordantes) ou tectônicos. Fenômenos metassomáticos são freqüentes (Wernick, 1972).

A área $\mathrm{N}$ representa a maior concentração de material granítico tardi- e póstectônico da Zona Cristalina Norte de São Paulo, formando tanto corpos isolados, circunscritos de dimensões médias a pequenas, quanto formando migmatitos (Härme, 1965; Oliveira, 1972; Penalva e Wernick, 1973; Wernick e Penalva, 1974a). Neste caso, as rochas gnáissicas encaixantes são cortadas, invadidas e assimiladas por material equigranular de composição granítica, originando migmatitos de blocos, estromatíticos, dobrados, de "schlieren", nebulíticos e homofânicos. As grandes áreas migmatíticas assim resultantes (Grupo Pinhal) são por sua vez cortadas e rodeadas por corpos pós-tectônicos equigranulares e de composição granítica, caracterizando polidiapirismo restrito (Fig. 3C).

Estudos realizados nos maciços de Pinhal e de Socorro em 1972 e 1973 (Wernick e Penalva, 1974b) evidenciam que a distribuição dos diferentes tipos estruturais de migmatitos guardam relações mais ou menos definidas com os corpos graníticos a eles associados. Estes são de caráter tardi- a pós-tectônicos, equigranulares ou porfirôides. A distribuição faz-se sob a forma de zonas concêntricas, de acordo com $o$ 
A-Complexo polidiapírico omitidos as complicapoes por falhamentos

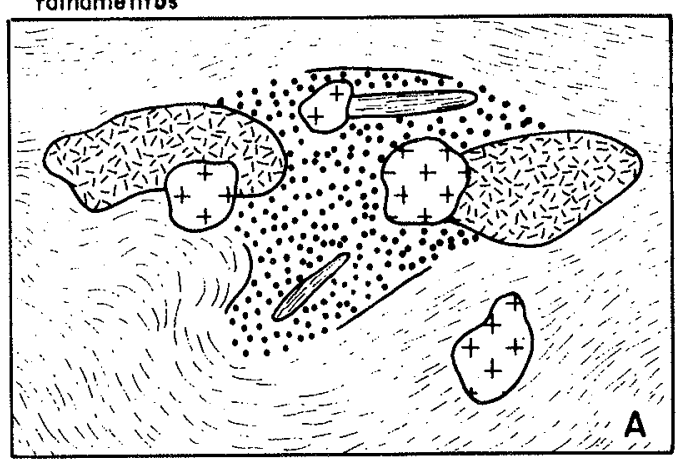

B-Complexo granítico de polidiopirismo restrito

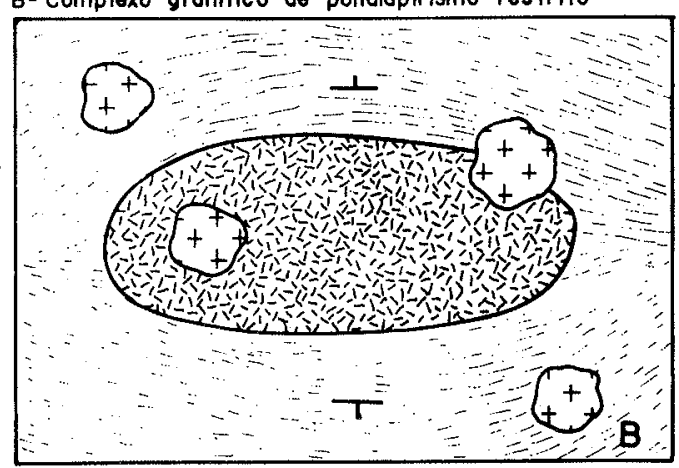

䧄谓 Granifos Tarditectônicos

$t^{+}+$Gronitos Postectónicos

$=-=$ Epimetomorfitos $\because \because \because \because$ Gronitos Sintectónicos

Fistos Gronitos Torditectonicos

$t_{+}^{+}$Granitos Postectônicos

Gnolsses a Anatexitos
C- Complexo migmatitico de polidiapirismo restrito

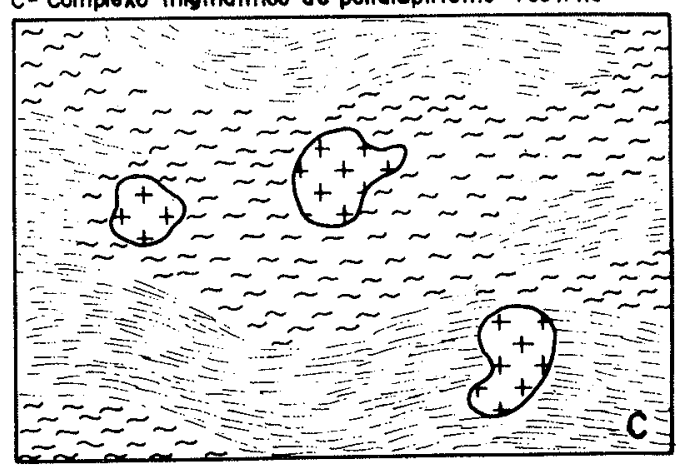

Dos. fremoleos 1900

Figura 3 - Esquemas de complexos graníticos polidiapíricos 
esquema simplificado da Fig. 4. A zona externa é formada por migmatitos acamados; a intermediária por migmatitos agmatíticos, de "schollen" e de "schlieren" e a central por migmatitos nebulíticos, de "schlieren" e homofânicos. Esta última exibe contatos gradacionais em relação ao núcleo granítico. Cada uma das zonas pode ocorrer com espessura variável, ou mesmo faltar. A auréola migmatítica, como um todo, ostenta espessura aparente variável, desde centenas de metros até alguns quilômetros. Sua forma pode ser arredondada, ovalada ou irregular. O processo de migmatização é geralmente acompanhado por fenômenos de feldspatização, mais ou menos acentuada, que pode afetar não sô todos os tipos de migmatitos mas também os gnaisses encaixantes, através do desenvolvimento de megacristais de microclina e/ou de oligoclásio. Os granitos formadores de migmatitos ocorrem, via de re-

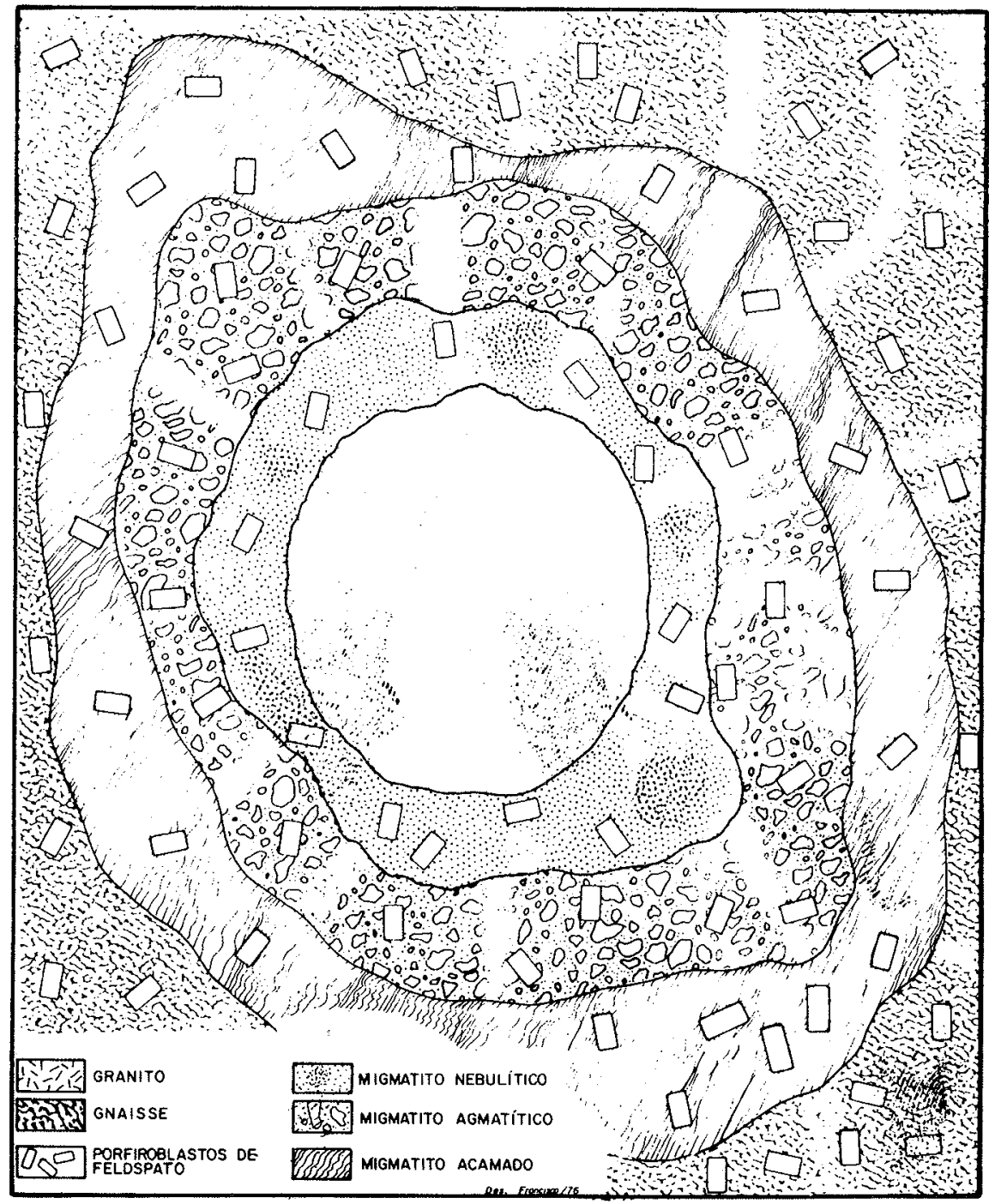

Figura 4 - Esquema da distribuição dos diferentes tipos de migmatitos em torno de granitos tarditectônicos relacionados a complexos polidiapíricos 
gra, sob a forma de várias intrusōes, relativamente próximas, resultando na formação de amplos complexos granítico-migmatíticos (Fig. 5). Devido a fenômenos de interferência, nesses complexos ocorrem migmatitos com estruturas polifásicas. Assim, são observáveis migmatitos acamados cujo paleossoma é formado por migmatitos nebulíticos ao lado de migmatitos agmatíticos com fragmentos de migmatitos acamados (Fig. 6). Dado o fato das intrusōes ocorrerem num certo intervalo de tempo, resulta que os processos metassomáticos acompanhantes são de natureza polifásica (Wernick et al., 197.6). O alojamento dos granitos formadores de migmatitos é controlado por estruturas dobradas e fraturas.

Em toda a região ocorrem, também, diques e "plugs" de granitos pórfiros relacionados à descompressão generalizada que caracteriza o estágio orogênico final (Wernick, 1972). Não são conhecidas efusivas ligadas aos depósitos molássicos.

Dados geocronológicos disponíveis indicam, para os granitos tardi- e pós-tectônicos, idades de 620 e 540 m.a., semelhantes às obtidas para rochas equivalentes do Maciço Mediano de Joinvile (Cordani e Bittencourt, 1967; Hasui e Hama, 1972; Cordani et al., 1973; Dehal et al.,1969; Wernick et al., 1976).

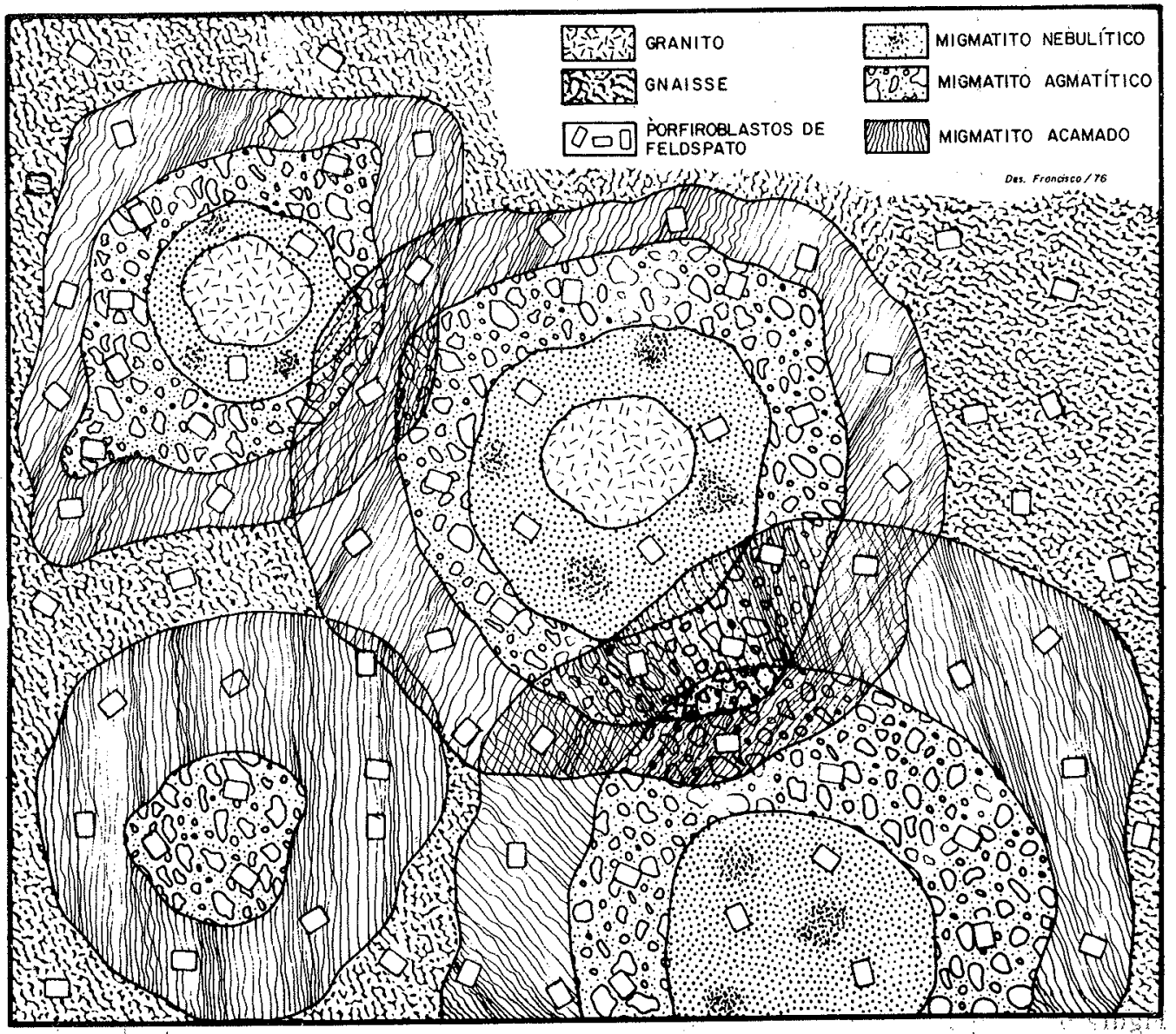

Figura 5 - Esquema de distribuição dos diferentes tipos de migmatitos em complexos graníticos polidiapíricos, ricos em granitos tarditectônicos 
Ā semelhança do Maciço Mediano de Pelotas, a Zona Cristalina Norte de São Paulo se mostra muito pobre em recursos metálicos, restritos principalmente a pequenas ocorrências de metais raros $(\mathrm{W}, \mathrm{Li}$ ou $\mathrm{U})$ associados a granitos das proximidades do contato tectônico entre a Zona Cristalina Norte de São Paulo e a Faixa de Dobramento Apiaí. Wolfrâmio ocorre em vieiros, associado a topázio e fluorita, no granito Itu e na região de Sorocaba. Essas mineralizações são insignificantes quando comparadas com as do Maciço Mediano de Pelotas, apesar da freqüência de fenômenos metassomáticos e pneumatolíticos observados em granitos da Zona Cristalina Norte de São Paulo e na Faixa de Dobramento Apiaí (granitos Perús, Nazaré, TícoTico, São Roque, etc.). Esses granitos geralmente são portadores de turmalina, associada ou não com fluorita.

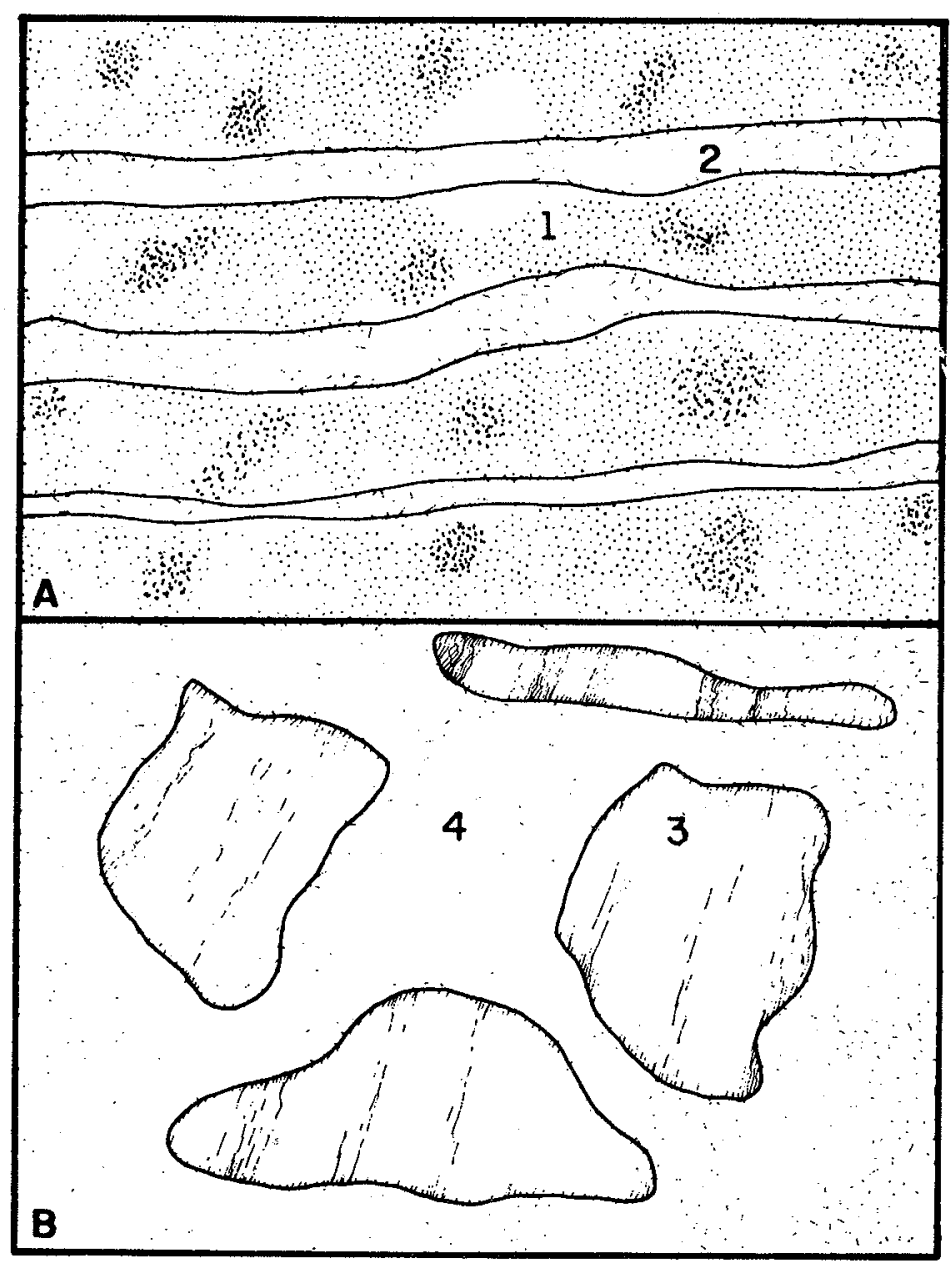

Figura 6 - Tipos de migmatitos polifásicos: A - migmatito acamado com paleossoma de migmatito nebulítico. (1) e neossoma granítico (2). B - migmatito agmatítico com paleossoma de migmatito acamado (3) e neossoma granítico (4) 
CONCLUSÕES A análise e interpretação sistemática das rochas graníticas do Sul do Brasil (Estados de SP, PR, SC e RS), em função da compartimentação estrutural do Sistema de Dobramento Ribeira, revela as seguintes feições gerais:

1) No Maciço Mediano de Pelotas (Formação Cambaí e Grupo Taboleiro) os granitos ocorrem aglutinados sob a forma de dois grandes complexos de natureza polidiapírica, formados por granitos sin-, tarḋi-e pós-tectônicos, cuja composição varia entre quartzo-diorítica e granítica, sendo esta predominante. O ciclo magmático encerra-se, nesse maciço, com a intrusão de "plugs" e diques de granitos pórfiros. Aos granitos estão associados importantes recursos metálicos $(\mathrm{Sn}, \mathrm{W})$, ligados a fenômenos de granitização em profundidade.

Os complexos situam-se junto ao contato tectônico entre o Maciço Mediano de Pelotas e a Faixa de Dobramento Tijucas; as intrusivas mais novas cortam ambas as unidades. As idades das rochas sin-, tardi- e pós-tectônicas situam-se, respectivamente, em torno de 650,610 e 550 m.a.

2) Na Faixa de Dobramento Tijucas (Formação Vacacaí e Botuverá) os granitóides são mesotectônicos, formando maciços circunscritos de composição granodiorítica e granítica. São dômicos, de injeção forçada e de polidapirismo restrito, com uma fase tarditectônica de $610 \mathrm{~m}$.a. e outra, pós-tectônica, de $525 \mathrm{~m}$.a.

Sua intrusão é controlada pelas estruturas dobradas. Como mineralizações associadas, quer diretas quer indiretas, ocorrem $\mathrm{Sn}, \mathrm{Cu}$ e $\mathrm{Au}$. Também aqui estão presentes diques ligados à fase de descompressão regional.

3) Granitos epitectônicos de caráter pós-orogênico, diferenciados ou não, é associados a diques de composição básica a ácida ocorrem ligados aos depósitos molassóides que margeiam a Faixa de Dobramento Tijucas, representados por material sedimentar e vulcânico depositado em bacias tectônicas das Formações Maricá e Garcias e Grupos Bom Jardim, Camaquã e Itajaí. São granitos que podem exibir mineralização de Au. Seu alojamento é controlado por fraturas.

4) No Maciço Mediano de Joinville (Complexo Cristalino dos Estados de SP e PR, Formação Setuva, porção norte do Grupo Taboleiro e extremidade ocidental do Embasamento do RS), observa-se certo zoneamento quanto à disposição das rochas graníticas. Na faixa NW, junto ao contato tectônico entre o Maciço Mediano de Joinvile e a Faixa de Dobramento Apiaí, ocorrem grandes complexos polidiapíricos formados por granitos sin-, tardi- e pós-tectônicos cuja composição varia entre quartzo-diorítica e granítica, e com características cata- a mesotectônicas. A faixa central é formada por complexos sin-, tardi- e pós-tectônicos de caráter polidiapírico ou não. São mais numerosos, porém menos extensos que os complexos da faixa NW. A faixa SE é formada por intrusões pós-tectônicas, mesotectônicas, alasquíticas e alcalinas cujo alojamento é controlado por fraturas. No Maciço ocorrem, também, as vulcânicas molássicas da Formação Campo Alegre e Grupo Castro (riolitos, dacitos, andesitos e material piro-clástico).

Os granitos sintectônicos revelam idades em torno de 650 m.a., os tarditectôni$\cos 620$ m.a. e os pós-tectônicos 540 m.a.; o vulcanismo molássico é ao redor de 525 m.a. Também ocorrem diques e "plugs" de natureza variada, com ampla distribuição, ligados à fase de descompressão regional. O Maciço Mediano de Joinvile carece de mineralizações notáveis. 
5) Cerca de $50 \%$ da área de exposição da Faixa de Dobramento Apiaí (Grupo São Roque e Açungui) é ocupada por rochas graníticas de composição variável entre diorîtica e graníticá, predominando granitos adamelíticos porfiróides. São intrusões mesotectônicas, tarditectônicas precoces e tardias e, subordinadamente, póstectônicas. Os complexos maiores são nitidamente polidiapíricos, com as rochas póstectônicas cortando ou rodeando grandes corpos tarditectônicos. O seu alojamento é controlado pelas estruturas dobradas. Também ocorrem vulcanitos molássicos (Grupo Castro) e "plugs" e diques de granitos pórfiros ligados à fase de descompressão regional. Associadas aos granitos, ocorrem mineralizações de $\mathrm{Pb}$ (com Sn, Au e $\mathrm{Ag}$ ) e Cu. Os granitos tarditectônicos estão datados em torno de $600 \mathrm{~m} . \mathrm{a}$. e os póstectônicos em cerca de $540 \mathrm{~m}$.a. Os vulcanitos molássicos têm idade ao redor de 425 m.a.

6) Também na Zona Cristalina Norte de São Paulo ocorre um grosseiro zoneamento na disposição das rochas graníticas. $\mathrm{Na}$ zona de contato tectônico, entre esta unidade e a Faixa de Dobramento Apiaí, ocorrem intrusões tardi- e pós-tectônicas, mesotectônicas, isoladas, de estrutura simples e dimensões variáveis. Possivelmente constituęm corpos marginais de complexos polidiapíricos maiores, deslocados ao longo da zona de transcorrência ali presente. Na parte central ocorrem complexos polidiapíricos cata- a mesotectônicos com fases sin-, tardi- e pós-tectônicas, e composição diorítica e granítica. Na parte norte ocorrem extensos complexos migmatíticos resultantes da penetração de material granítico traditectônico que, por sua vez, são cortados e rodeados por intrusões pós-tectônicas menores. A idade das diversas fases intrusivas é a mesma observada para as equivalentes no Maciço Mediano de Joinvile. స Vão ocorrem mineralizações metálicas de monta nem vulcanitos molássicos. Entretanto, estão presentes de maneira generalizada, diques de granitos pórfiros ligados à fase de descompressão regional.

7) Do exposto verifica-se que as rochas granitóides das diversas unidades estruturais (Maciço Mediano e Faixa de Dobramento), exibem freqüência, natureza, composição, controle de alojamento e mineralizações distintas:

a) Quanto à freqüência: os granitos são mais raros no Maciço Mediano de Pelotas e mais freqüentes no Maciço Mediano de Joinvile e na Zona Cristalina Norte de São. Paulo. Quanto às faixas de dobramento, a de Apiaí é mais abundante em granitos què a Faixa de Dobramento Tijucas.

b) Quanto à natureza dos complexos: no Maciço Mediano de Pelotas ocorrem grandes complexos polidiapíricos, cata-e mesotectônicos. No Maciço Mediano de Joinvile também ocorrem grandes complexos polidiapíricos, cata- e mesotectônicos. A este somam-se outros complexos menores, cata- e mesotectônicos e de polidiapirismo restrito, ao lado de pequenas intrusões mesotectônicas, pós-tectônicas, de natureza alasquítica ou alcalina e desprovidas de polidiapirismo. A Zona Cristalina Norte de São Paulo é semelhante ao Maciço Mediano de Joinvile. Faltam entretanto as intrusões alcalinas. Por outro lado ocorrem grandes complexos migmatíticos tarditectônicos de polidiapirismo restrito. Na Faixa de Dobramento Tijucas, os granitos são mesotectônicos, de dimensões médias e de polidiapirismo restrito. Na Faixa de Dobramento Apiaí ocorrem intrusões mesotectônicas e tarditectônicas que atingem grandes dimensões e são de caráter polidiapírico mais intenso. 
Ligados aos depósitos molássicos associados à Faixa de Dobramento Tijucas, ocorrem pequenos granitos pós-tectônicos de natureza epitectônica, simples ou dıferenciados.

c) Quanto à composição: os grandes complexos polidiapíricos, com fases sin-, tardie pós-tectônicas, tèm composição variável entre diorítica a granítica. Entre as intrusōes tarditectônicas simples ou polidiapíricas predominam granitos porfiróides de composição global adamelítica. Entre os corpos pós-tectônicos predominam os de composição granítica, ganhando expressão no Maciço Mediano de Joinvile os granitos com tendência alcalina. Entre os granitos pós-orogênicos, ligados à fase molássica, também predominam corpos de composição granítica.

d) Quanto ao controle do alojamento: os grandes maciços polidiapíricos com fasessin-, tardi- e pós-tectônicas se situam preferencialmente junto às zonas tectônicas que separam os Maciços Medianos das Faixas de Dobramento. Os granitos tarditectônicos são controlados preferencialmente pelas estruturas dobradas, alojando-se nos núcleos de anticlinais e anticlinórios. Os granitos pós-tectônicos exibem controle variado, quer por estruturas dobradas, quer cortando ou rodeando maciços graníticos mais antigos ou ocorrendo associados a zonas de fraturas e falhas. As intrusões dos granitos associados à fase molássica são controladas por fraturas. Estão restritos à área de contato entre o Maciço Mediano de Joinvile e a Faixa de Dobramento Tijucas. Associados aos mesmos ocorrem diques de composiçāo básica e ácida.

Os granitos sintectônicos estāo restritos aos Maciços Medianos. Granitos tardi-e pós-tectônicos ocorrem tanto nos Maciços quanto nas Faixas de Dobramento. Os granitos tarditectônicos são os mais freqüentes, considerando-se todo o Sistema de Dobramento Ribeira. Granitos sin-e pós-tectônicos são relativamente raros, os últimos geralmente exibindo dimensōes reduzidas.

e) Quanto à mineralização: as mineralizaçōes direta ou indiretamente associadas às diversas unidades estruturais do Sistema de Dobramento Ribeira são variáveis. No Maciço Mediano de Pelotas ocorrem Sn e W; na Faixa de Dobramento Tijucas Sn, $\mathrm{Cu}$, e Au e na Faixa de Dobramento Apiaí Pb e Zn como metais de importância econômica. No Maciço Mediano de Joinvile e na Zona Cristalina Norte não são conhecidas mineralizações metálicas notáveis. Alguns granitos associados à fase molássica apresentam ocorrência de Au.

8) Os vulcanitos molássicos têm distribuição variável. Faltam no Maciço Mediano de Pelotas e na Zona Cristalina Norte. Ocorrem junto ao contato entre o Maciço Mediano de Joinvile e a Faixa de Dobramento Tijucas, no interior do Maciço Mediano de Joinvile e na Faixa de Dobramento Apiaí.

9) Em todas as unidades estruturais ocorrem diques e "plugs" de granitos pórfiros associados à fase de descompressāo regional da área geossinclinal.

10) Os granitos pós-tectônicos das faixas de dobramento são caracterizados, predominantemente, por um caráter levemente subvulcânico, atestadio pela ocorrência generalizada de quartzo arredondado e sua associação com numerosos diques e "plugs" de granitos pórfiros. São geralmente pobres em pegmatitos e as auréolas de contato são de pouca expressāo. Tais dados indicam resultarem de magmas superaquecidos e de caráter "anidro".

11) As dataçōes geocronológicas das fases sin- tardi- e pós-tertônicas nas diversas unidades estruturais, são aproximadamente equivalentes, dentro da natural defasa- 
gem no espaço e no tempo esperada para as diversas fases evolutivas de um cinturão orogênico.

12) Os dados acima analisadós indicam que, no Sistema de Dobramento Ribeira, estruturado sob forma de Faixas de Dobramento e Maciços Medianos, os diversos compartimentos exibem características magmáticas distintas quanto à freqüência, estrutura, controle de alojamento e mineralização associada (Wernick e Penalva, 1976; Bettencourt et al., 1976).

13) As características do magmatismo ácido do Sistema de Dobramento Ribeira mostram as feições gerais observadas em áreas geossinclinais com vulcanismo básico fraco ou ausente, na fase de subsidência; fraco vulcanismo, com tendências ácidas, na fase de diferenciação e intenso vulcanismo granítico no estágio de fechamento (geossinclíneos com perfil siálico, Kuznetsov, 1971).

\section{BIBLIOGRAFIA}

ALMEIDA, F.F.M. de - 1969 - Diferenciação tectônica da Plataforma Brasileira. An. XXIII Congr. Bras. Geol., pp. 29-46, Salvador.

ALMEIDA, F.F.M. de - 1971 - Geochronological division of the Precambrian of South America. Rev. Bras. Geoc., 1(1):13-21, São Paulo

BETTENCOURT, J.S.; WERNICK, E. e PENALVA, F. -... 1976 -... Contribuição à metalogenia do Sistema de Dobramento Ribeira. An. XXIX Congr. Bras. Geol., Belo Horizonte (no prelo).

CARVALHO, P.F. de, e PINTO, E.A. - 1938 - Reconhecimento geológico no Estado de Santa Catarina. DNPM-SGM, Bol. 92, Rio de Janeiro.

CASTRO, E.C. de, e CASTRO, V.H.S. de - 1969 - Geologia da Quadrícula de Laguna, SC. DNPM, Porto Alegre, (inédito).

CORDANI, U.G. --- 1974 - Comentários sobre as determinações geocronológicas disponíveis nas Folhas Asunción e Curitiba. In. "Carta Geológica do Brasil ao Milionésimo. Folha Asunción -- SG-21 e Folha Curitiba SG-22. T'exto Explicativo", pp. 58-67, MME-DNPM, Brasília.

CORDANI, U.G. e BITTENCOURT, I. - 1967 - Determinação de idade potássioargônio em rochas do Grupo Açungui. An. XXI Congr. Bras. Geol., pp. 218-223, Curitiba.

CORDANI, U.G. e KAWASHITA, K. - 1971 - Estudo geocronológico pelo método Rb. Sr de rochas graníticas intrusivas no Grupo Açungui. An. XXV Congr. Bras. Geol., pp. 105-110, São Paulo.

CORDANI, U.G.; DELHAL, J. e LEDENT, D. - 1973 - Orogenèses superposées dans le Precambrien du Brèsil sud-oriental (Êtats de Rio de Janeiro et de Minas Gerais). Rev. Bras. Geoc., 3(1):1-22, São Paulo.

CORDANI, U.G. HALPERN," M. e BERENHOLC, M. - 1974 - Comentários sobre as determinações geocronológicas da Folha de Porto Alegre. In "Carta Geológica do Brasil ao Milionésimo. Folhas Porto Alegre (SH-22) e Lagoa Mirim (SI-22). Texto explicativo", pp. 70-84, MME-DNPM, Brasília.

COUTINHO, J.M.V. - 1953 - Petrologia da região de São Roque, SP. Fac. Fil. Ciênc. Letr., USP, Bol. 159, (Mineralogia 13), 86 pp., São Paulo.

COUTINHO, J.M.V. - 1972 - Petrologia do Pré-Cambriano em São Paulo e arredores. Inst. Geoc., USP, Bol. 3:5-19, São Paulo. 
DELHAL, J.; LEDENT, K.; CORDANI, U.G. 1969 Ages $\mathrm{Pb} / \mathrm{U}, \mathrm{Sr} / \mathrm{Rb}$ et $\mathrm{Ar} / \mathrm{K}$ des formations metamorphiques et granitiques du Sud-Est du Brèsil (Estado do Rio de Janeiro et de Minas Gerais). Annal. Soc. Gcol. Bélgique, 92:271-283, Bruxelles.

EBERT, H. - 1971 - O Grupo Guaratubinha no norte do Estado de Santa Catarina. An. XXV Congr. Bras. Geol., 1:147-165, São Paulo.

ELLERT, R. - 1964 - Geologia da região de Mairiporã, SP: Tese de Livre Docência. Fac. Fil. Ciênc. Letr., USP, São Paulo, (inédito).

FERREIRA, L.A.D. - 1969 - Relatório da geologia da Quadrícula de Rio Fortuna, SC. DNPM, Porto Alegre, (inédito).

FRANCO, R.R. - 1958 - Contribuição ao conhecimento das rochas termometamórficas da Série São Roque. Fac. Fil. Ciênc. Letr., USP, Bol. 189, (Mineralogia 14), 81 pp., São Paulo.

FUCK, R.A., MARINI, O.J. e TREIN, E. - 1967 - Contribuição ao estudo das rochas graníticas do Estado do Paraná. Bol. Paran. Geoc., 23-25:183-219, Curitiba.

GOÑI, J.G. - 1961 - O rapakivi Lavras, jazidas metalíferas associadas, Rio Grande do Sul, Brasil. UFRGS, Esc. Geol. Bol. 7, Porto Alegre.

HASUI, Y. - 1973 - Tectônica da área das Folhas de São Roque e Pilar do Sul. Tese de Livre Docência. Inst. Geoc., USP, 190 pp., São Paulo, (inédito).

HASUI, Y.; PENALVA, F. e HENNIES; W.T. - 1969 - Geologia do Grupo São Roque. An. XXIII Congr. Bras. Geol., pp. 101-134, Salvador.

HASUI, Y. e HAMA, M. - 1972 - Geocronologia do Grupo São Roque pelo método potássio-argônio. Rev. Bras. Geoc., 2(1):8-24, São Paulo.

HÁSUI, Y.; CARNEIRO, C. DAL R. e COIMBRA, A.M. - 1975 - The Ribeira Folded Belt. Rev. Bras. Geoc., 5(4):257-266, São Paulo.

HASUI, Y. e SADOWSKI, G.R. - 1976 - Evolução do precambriano na região sudeste do Estado de São Paulo. Rev. Bras. Geoc., 6(3):182-200.

HÄRME, M. - 1965 - On the potassium migmatites of southern Finland. Bull. Comm. Géol. Finalande, 219, 43 pp.

HENNIES, W.T.; HASUI e PENALVA, F. - 1967 - O falhamento transcorrente de Taxaquara. An. XXI Congr. Bras. Geol., pp. 159-168, Curitiba.

JOST, H. - 1970 - Esboço geológico da Folha Cabeceiras do Rio Vacacaí, São GabrielLavras do Sul, RGS, UFRGS, Esc. Geol., Bol. 16, Porto Alegre.

KNIJNIK, P.R. e POZZA, E.P. - 1971 - Geologia da área Bagé-São Gabriel, Rio Grande do Sul. DNPM-CPRM, Porto Alegre, (inédito).

KUZNETSOV, Yu, A. - 1971 - Principal types of magma-controlling structures and magmatic formations. Internat. Geol. Rev., 13(11):1585-1599.

LEINZ, V. - 1945 - Geologia da área mineralizada de estanho e tungstênio no Estado do Rio Grande do Sul. DNPM-DFPM, Bol. 70, Rio de Janeiro.

LEINZ, V. BARBOSA, A.F. e TEIXEIRA, E. - 1941 - Mapa geológico CaçapavaLavras. Secr. Agric., Ind. Com., Dir. Prod. Mineral, Bol. 90, Porto Alegre.

MAACK, R. - 1947 - Breves notícias sobre a geologia dos Estados do Paraná e Santa Catarina. Arq. Biol. Tecn., 2:63-154, Curitiba.

MAACK, R. - 1961 - Sobre a ocorrência de granitos alcalinos no Estado do Paraná e sua posição dentro das fases orógenéticas algonquianas. Univ. Fed. Paraná, Bol. Geologia 4, 52 pp., Curitiba.

MARMO, V. - 1971 Granite petrology and the granite problem. Development in petrology 2, Elsevier, New York.

MAU, H. 1962 Atividades magmáticas na região de Caçapava-Lavras, Estado do Rio Grande do Sul. Fac. Fil. Ciênc. Letr., USP, Bol. 264 (Geologia 19), 64 pp., São Paulo.

MELCHER. G.C. e MAU, H. ․ 1960 - Novas observações geológicas na regiāo de Caçapava do Sul, Rio Grande do Sul. An. Acad. Bras. Ciênc, 32: 43-50, Rio de Janeiro. 
MELCHER, G.C.; GOMES, C.B.; CORDANI, U.G.; BETTENCOURT, J.S.; DAMASCENO, E.C.; GIRARDI, A.V. e MELFI, A.J. 1973 - Geologia e petrologia das rochas metamórficas e graníticas associadas do Vale do Rio Ribeira de Iguape, SP e PR. Rev. Bras. Geoc., 3(2):97-123, São Paulo.

MINIOLI, B. - 1971 - Determinaçōes potássio-argônio em rochas localizadas no litoral norte do Estado de São Paulo. An. Acad. Bras. Ciênc., 43(2):443-448, Rio de Janeiro.

MINIOLI, B. e KAWASHITA, K. - 1971 - Contribuição à estratigrafia eopaleozóica do "Escudo Riograndense". An. XXV. Congr. Bras. Geol., 1:193-198, São Paulo.

MORAES REGO, L.F. de, e SOUZA SANTOS, T.D. de - 1938 - Contribuição para o estudo dos granitos da Serra da Cantareira. Bol. Inst. Pesq. Tecnol., 18, São Paulo.

OLIVEIRA, M.A.F. de - 1972 - Petrologia das rochas metamórficas da região de São José do Rio Pardo, SP. Rev. Bras. Geoc., 3(3):257-278, São Paulo.

PENALVA, F. e WERNICK, E. - 1973 - Feições estruturais de migmatitos ao norte e sul da falha de Jacutinga, leste do Estado de São Paulo. Ciência e Cultura, 25:183, São Paulo.

PICADA, R.S. - 1967 - Estudos preliminares sobre a evoluçāo geoquímica e mineralógica do maciço granítico Encruzilhada (R.G.S.). UFRGS, Esc. Geol., Bol. Esp., 14:1-87, Porto Alegre.

PICADA, R.S. - 1971 - Ensaio sobre a tectônica do Escudo Sulriograndense. Caracterização do sistema de falhas. An. XXV Congr. Bras. Geol., 1:167-191, São Paulo.

RIBEIRO, M; BOCGHI, P.R.; FIGUEIREDO Fo, P.M. e TESSARI, R.I. - 1966 - Geologia da Quadrícula de Caçapava do Sul, R.G.S. DNPM-DFPM, Bol. 127, Rio de Janeiro.

SADOWSKI, G.R. - 1974 - Tectônica da Serra de Cubatāo, SP. Tese de doutoramento, Inst. Geoc., USP, 159 pp., (inédito).

SCHULZ JR. A.; ALBUQUERQUE, L.F.F. de, e GIFFONI, L.E. - 1969 - Geologia da Quadrícula de Rio do Sul, SC. DNPM, Porto Alegre, (inédito).

SCHULZ JR., A.; ALBUQUERQUE, L.F.F. de; e RODRIGUES, C.S. - 1970 - Geologia da Quadrícula de Florianópolis, SC. DNPM-CPRM, Porto Alegre, (inédito).

STEPHANSSON, O. - 1975 - Polydiapirism of granitic rocks in the Svecofennian of central Sweden. Precambrian Research, 2:189-214.

TEIXEIRA, C.A.S. - 1969 - Relatório preliminar das Quadrículas de Morro da Fumaça e Braço do Norte, SC. DNPM, Rel. int., Porto Alegre, (inédito).

TESSARI, R.I. e FIGUEIREDO FILHO, M.P. - 1966 - Geologia da Quadrícula de Cerro das Cotias, Encruzilhada do Sul. DNPM-DFPM, Porto Alegre, (inédito).

TESSARI, R.I. e PICADA, R.S. - 1966 - Geologia da Quadrícula de Encruzilhada do Sul, Rio Grande do Sul, Brasil. DNPM-DFPM, Bol. 124, 147 pp., Rio de Janeiro.

TREIN, E. e FUCK, R.A. - 1967 -- O Grupo Castro. Bol. Paran. Geoc., 23-25:257-305, Curitiba.

VANDOROS, P. e FRANCO, R.R. - 1966 - Determinnação de idade de granitos da região de Moji das. Cruzes, São Paulo, pelos métodos potássio-argônio e rubídio-estrôncio. An. Acad. Bras. Ciênc., 38(2):289-292, Rio de Janeiro.

WERNICK, E. - 1972a - A geologia do maciço granítico de Morungaba, leste do Estado de São Paulo. Esc. Eng., USP, Bol. Geol. 16, 110 pp., São Carlos.

WERNICK, E. - 1972b - Granitos pórfiros dos arredores de Serra Negra, Valinhos e Amparo e suas relações com o maciço de Morungaba, leste do Estado de São Paulo. Rev. Bras. Geoc., 2(1):129-138, São Paulo.

WERNICK, E. GOMES, C.B. - 1974 - Granitos e metamorfismo no Vale Ribeira de Iguape, SP e PR. An. XXVIII Congr. Bras. Geol., 5:145-154, Porto Alegre.

WERNICK, E. e PENALVA, F. - 1974a - Migmatização e feldspatização de charnockitos e granulitos no leste paulista e sul de Minas Gerais. An. XXVIII Congr. Bras. Geol., 5:155-160, Porto Alegre. 
WERNICK, E. e PENALVA, F. 1974b Goologia dos maciços graníticos de Pinhal e Socorro, SP e MG, (inédito).

WERNICK, E.; OLIVEIRA, M.A.F. de; KAWASHIIA, K; CORDANI, U.G. e DELHAL, J. - 1976 - Estudo geocronológico pelo método $\mathrm{Rb} / \mathrm{Sr}$ em rochas do Bloco Jundiaí. Rev. Bras. Geoc., 6(2):125-135, São Paulo.

WERNICK, E.; PANTOJA, J.L. e NICOLA, J.P. 1976 - Megacristai de microlina do complexo granítico de Socorro, SP e MG. An. XXIX Congr. Bras. Geol., Belo Horizonte, (no prelo).

WERNICK; E. e PENALVA, F. - 1976 - Rochas graníticas do Sul do Brasil III Congr. Lat. Amer. Geol., Acapulco, (no prelo). 